\title{
Heat Transfer Correlations on Combustion Chamber Surface of Diesel Engine - Experimental Method
}

\author{
Shivakumar Nagareddy ${ }^{*}$, Ajeet Kumar ${ }^{1}$, Abhilash Rai Sharma ${ }^{1}$ and Amit Kumar ${ }^{1}$ \\ ${ }^{1}$ Mechanical Engineering Department, Aarupadai Veedu Institute of Technology, Chennai, India.
}

\begin{abstract}
Modification and control of recently developing engines have much important towards better fuel economy and reduction in exhaust emissions from an engine. Since the ignition takes place at high compression (or) self ignition of temperature in case of diesel engines, the temperature distribution and heat flux on the combustion chamber surface are an important phenomenon.

While modifying the profile of combustion chamber of diesel engine, it is important to relocate the hot spot regions on the combustion chamber surface which supports combustion initiation. With these hot spot regions on combustion chamber surface regulates/controls ignition delay period which results in controlled detonation. In diesel engines, controlled detonation which in turn improves engine performance and reduction in emissions. Therefore, to include the hot spot regions at proper locations, it is required to measure the temperature values at different locations/coordinates with the help of thermocouples on the cylinder head surface exposed to combustion chamber. Also the adiabatic flame temperature, the engine performance parameters, heat balance date, convection and radiation heat transfer related terms were calculated and analyzed. The efficient engine combustion chamber is developed with the help of all these measured/calculated values.
\end{abstract}

Keywords: Heat Transfer Analysis, Diesel engine combustion chamber, Temperature Distribution on cylinder head, Heat Transfer from combustion chamber

\section{* Corresponding author}

Shivakumar Nagareddy

shiva.thermal@gmail.com

Adress Mechanical Engineering

Department, Aarupadai Veedu Institute of Technology, Chennai, India.

Tel:+903122028653

Fax: +903122028639

Manuscript Received 18.06.2018

Revised 15.09.2018

Accepted 20.09.2018

Doi:10.30939/ijastech..434331

\section{Introduction}

Diesel engines are being extensively used for rail and road transportation, agriculture applications and power generation. Increasing demand and depleting fossil fuels have lead to research and development on production of energy efficient engines. Minimizing the energy losses in the engine definitely improves the power output and efficiency of the engine. In order to improve that performance of the engine, many experimental and theoretical investigations have been carried out elucidating the heat transfer characteristics of compression ignition engines.

Proper design of the combustion chamber is at least as important in the CI engine as in the SI engine. In the SI engine, a nearly homogeneous mixture enters the cylinder, is compressed, and the ignited by means of a spark plug. The fuel and air are mixed in the carburetor. In the
CI engine, on the other hand, only the air is compressed in the cylinder and the fuel is injected during a period of 30 to 35 degrees of crank angle. In this short period of time, the fuel and air must be mixed. In essence, the mixing portion of the SI engine carburetor's duties is performed within the combustion chamber in a CI engine. Consequently, the combustion chamber in a $\mathrm{CI}$ engine must be designed to provide for this mixing of fuel and air.

$\mathrm{NO}_{\mathrm{x}}$ emission increases with increase in in-cylinder temperature and the peak $\mathrm{NO}_{\mathrm{x}}$ level occur at combustion peak temperatures which occur between start of combustion and in-cylinder peak pressure [1].

Burned zone temperature (localized in-cylinder temperature) is significantly higher than the global/average in-cylinder temperature during the combustion. The reason for this significant difference is due to localized phenomenon i.e., the in-cylinder temperature varies with 


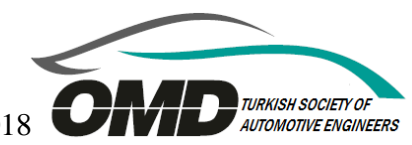

respect to spatial coordinates in the combustion chamber [2].

The combustion temperature was not sufficiently high to make soot inception or to continue their growth in most regions, except for several high-temperature regions. This is analogous to the inverse diffusion flame, where the nascent soot particles can be transported away from the flame front by thermo-phoretic force toward lower temperature regions [3-6]. It is noted that an individual soot particle experiences the process of evolution and oxidation along the diesel spray flame axis and in the radial direction during conventional diesel combustion [7, 8], even though partially premixed combustion could be achieved in low temperature combustion.

$\mathrm{NO}_{\mathrm{x}}$ forms in the lean mixture zone where flame temperature is above $2200 \mathrm{~K}$, whereas soot forms in the rich mixture zone above $1800 \mathrm{~K}$. Conventional combustion overleaps the formation zones of $\mathrm{NO}_{\mathrm{x}}$ and soot, but LTC techniques like HCCI and PCCI avoid these zones and reduce $\mathrm{NO}_{\mathrm{x}}$ and soot simultaneously [9-11]. Interestingly they observed that even on higher EGR, higher biodiesel content showed lowest ignition delay and they suggested that ignition delay relied more on chemical kinetics mechanism than the temperature reduction made by EGR. However, shorter ignition delay may also produce less $\mathrm{NO}_{\mathrm{x}}$ if the ignition delay is short enough to make a weak mixture [12].

Exergy destruction rate increased with increasing the dead state temperature [13]. The paper reports an application of 3D-CFD in-cylinder simulations to estimate the wall heat fluxes through the combustion chamber walls of a high performance Diesel engine. The work focuses on the role of heat transfer models, emphasizing their requirements correct estimation of the engine thermal balance. Two heat transfer models are analyzed; the widely adopted model developed by Angelberger and the novel GruMo-UniMORE one, recently proposed by the Gruppo Motori of the University of Modena e Reggio Emilia and implemented in the STAR-CD solver. Once the 3D-CFD model has been generated and reasonably validated against experimental in-cylinder pressure trace and IMEP, the heat fluxes are calculated and compared [16].

For the single injection pattern, differences in wall heat transfer coefficient before the start of combustion are mainly driven by changes in the flow field. After the start of combustion, differences in in-cylinder thermodynamic conditions also contribute to reach higher wall heat transfer coefficient levels than in the motored condition case. For multiple injection patterns, the greatest differences in wall heat transfer take place after the start of combustion and are mainly driven by changes in the in-cylinder thermodynamic conditions since no significant changes are observed in the characteristic velocity [17]. EGR showed a significant influence on fire deck temperatures and on heat flux. This finding differs from some reports in the

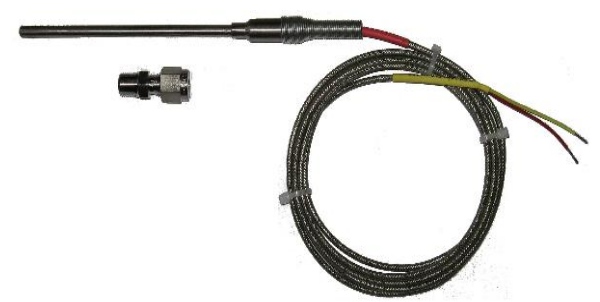

Fig. 1. K-type, compression fitting Cromel-Alumel thermocouple

literature which found no significant effect of EGR on those variables. The effect of EGR was to reduce wall temperatures and heat flux [18].

Impinging jet ignition characteristics was investigated under different wall temperatures. Flame area reduced at low temperature and decreased more sharply in the low temperature zone. Total flame luminosity reduced and more time needed to reach the saturation under low wall temperature [20].

To develop the hot spot regions at the correct positions on the combustion chamber surface of diesel engine, the thermocouples were installed on to the cylinder head to measure the temperature ranges on the surface of combustion chamber. Cromel/Alumel Transition K-type thermocouples are used for the temperature measurement [21].

In this study, the temperature ranges on the combustion chamber surface were measured using thermocouples and the values of convection heat transfer coefficient, emissivity and radiation heat transfer values are calculated. These calculated/measured values are required for the efficient design of combustion chamber including piston crown surface.

Table 1. Description of Cromel/Alumel thermocouple

\begin{tabular}{|l|l|}
\hline \multicolumn{1}{|c|}{ Type } & \multicolumn{1}{c|}{ Transition K-type } \\
\hline Model & HT-04 \\
\hline Protective Tube & MI SS316 \\
\hline Dimension in $\mathrm{mm}$ & OD-4mm, L-150mm \\
\hline Cable & Braided, Size-7*36, L-1m \\
\hline Compression Fitting & $\begin{array}{l}\text { Adjustable SS Ferrule Lock } \\
\text { able having thread M10*1 }\end{array}$ \\
\hline Termination Style & Pin type lug \\
\hline Accuracy Standard & IS2054 \\
\hline Operating Temperature & 0 to $1300^{\circ} \mathrm{C}$ \\
\hline
\end{tabular}

\section{Experimental Work}

Thermocouple used for the measurement of temperature on the cylinder head surface exposed to combustion chamber is based on its operating range and compression fitting. Figure 1 illustrates the thermocouple that was used in experiments. The Cromel/Alumel is the 


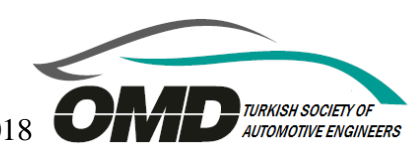

thermocouple material selected for the measurement of temperature and its maximum operating range is $1300^{\circ} \mathrm{C}$. Specifications of the thermocouple is given in Table 1.

Kirloskar diesel engine, which is shown on figure 2, is chosen for combustion chamber modification/temperature distribution measurement on cylinder head surface. Technical properties of the engine is seen on Table 2.

Table 2. Engine specifications

\begin{tabular}{|l|l|}
\hline B.H.P & $5 \mathrm{hp}$ \\
\hline Speed & $1500 \mathrm{rpm}$ \\
\hline Bore & $80 \mathrm{~mm}$ \\
\hline Stroke & $110 \mathrm{~mm}$ \\
\hline Type & Single Cylinder 4S Diesel Engine \\
\hline Fuel & Diesel \\
\hline Loading Type & Rope Brake Loading \\
\hline Cooling Type & Water Cooling \\
\hline
\end{tabular}

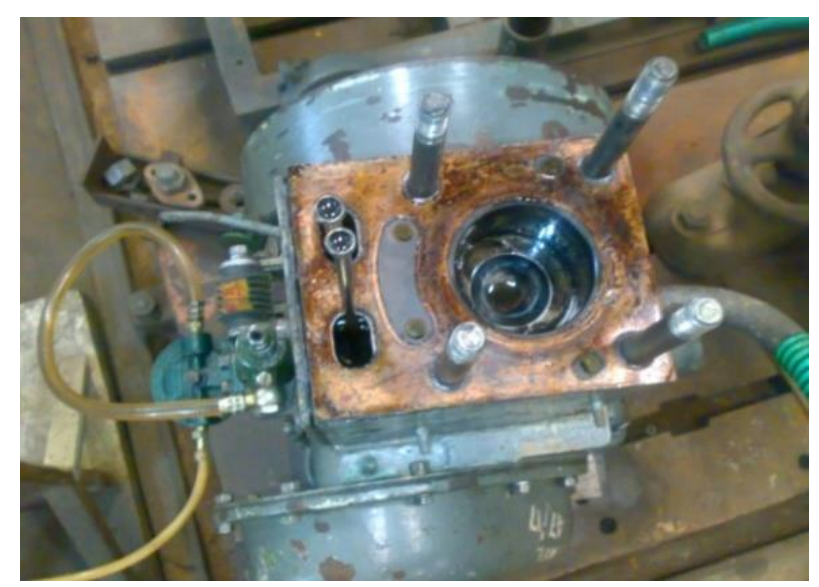

Fig. 2. Kirloskar diesel engine

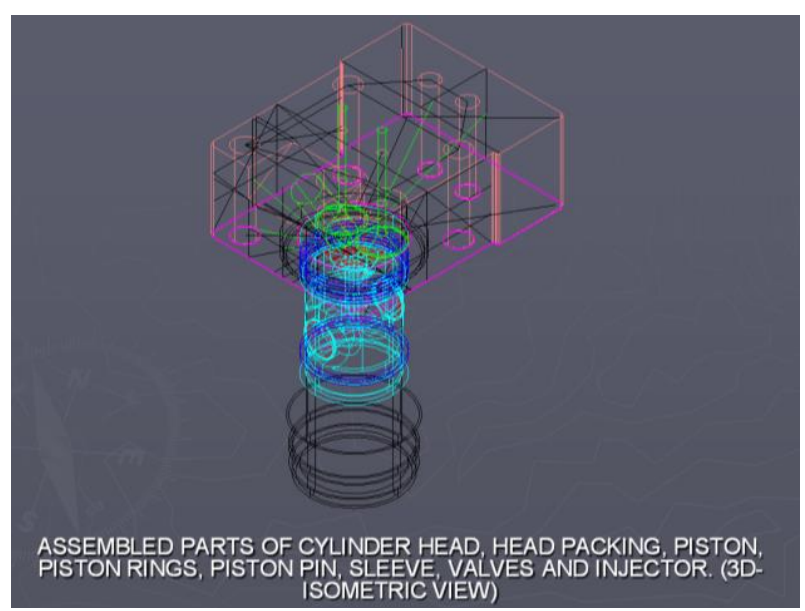

Fig. 3. CAD Model (Wireframe) of piston, cylinder head and cylinder sleeve assembly
To install/fit the thermocouples through cylinder head which is incorporated with water jacket, provisions for inlet and exhaust manifolds, valves, push rods, fuel injector and foundation bolts, CAD model was done in which the paths were found for fixing thermocouples with any restrictions with respect to compression leakage from engine cylinder and water leakage from water jacket.

The CAD model of piston, cylinder liner and cylinder head with fuel injector and valves assembly is as shown in figure 3 .

The cylinder head with fabricated sleeves for fixing thermocouples is as shown in figure 4. Figures 5 and 6 show the cylinder head fitted with thermocouples through sleeves fabricated.

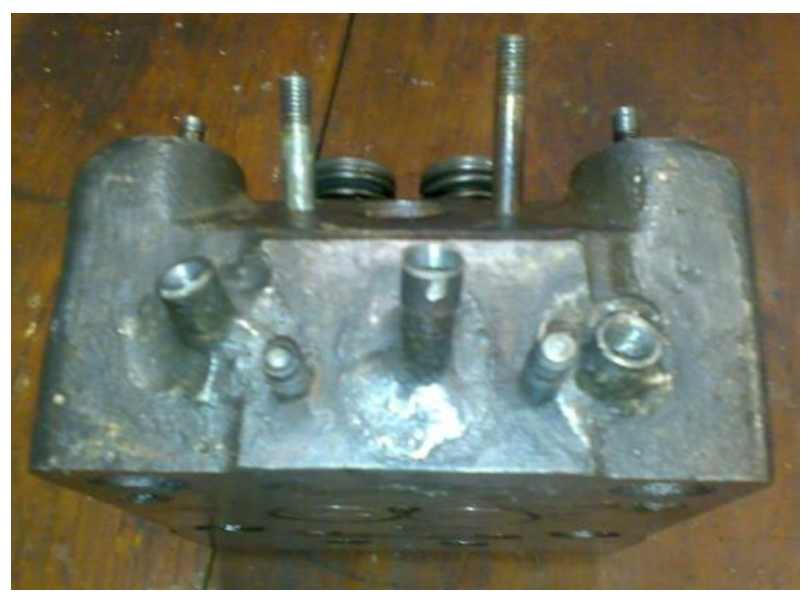

Fig. 4. Cylinder Head with fabricated slaves for fixing thermocouples

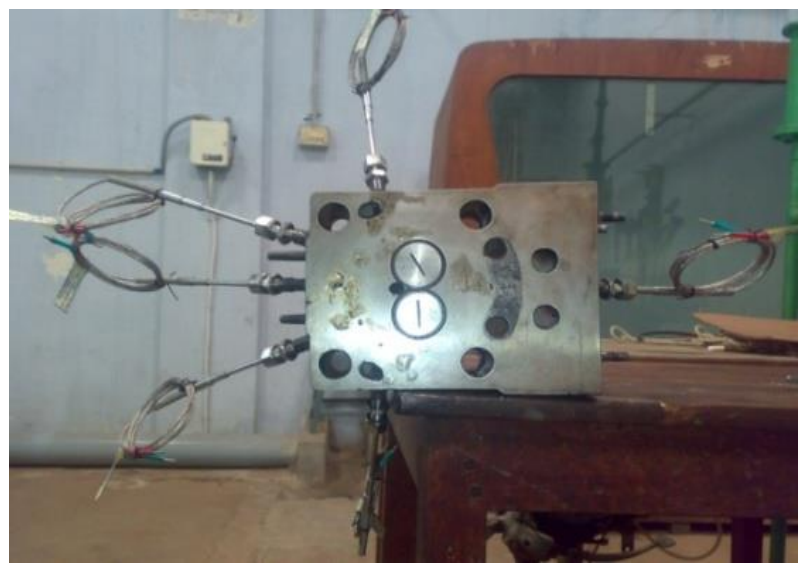

Fig. 5. Cylinder Head with fitted thermocouples 


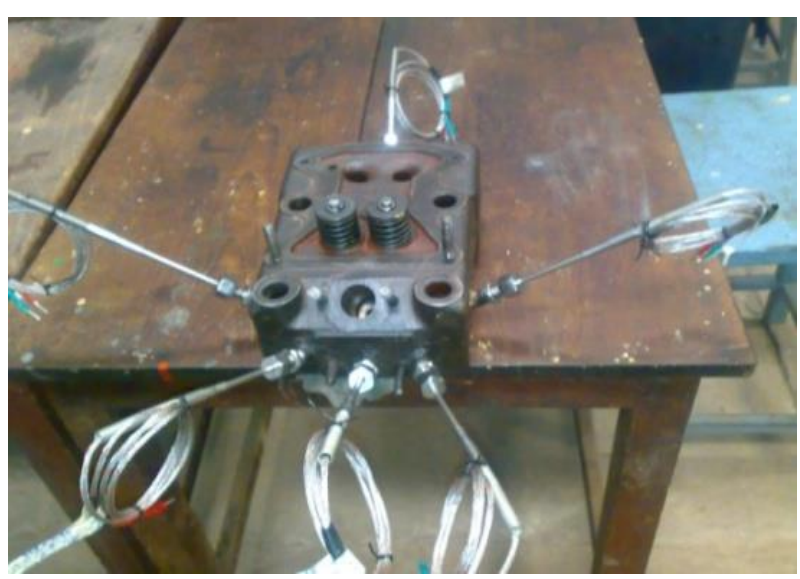

Fig. 6. Cylinder Head with fitted thermocouples

Finally, the installed thermocouples with Kirloskar diesel engine is tested for temperature measurement over cylinder head surface exposed to combustion chamber. The engine with installed thermocouples is as shown in figure 7.

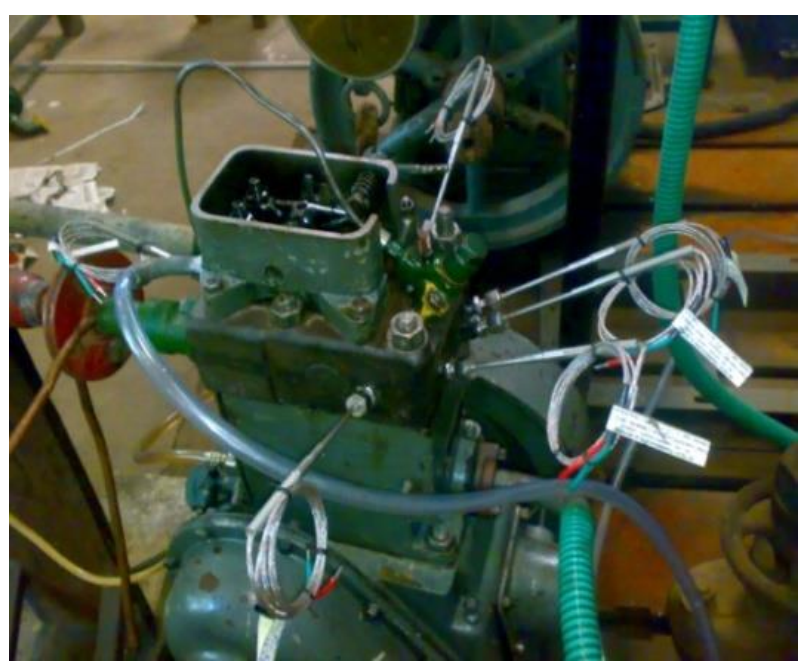

Fig. 7. Kirloskar diesel engine with installed thermocouples

\section{Results and Discussions}

The measured values of temperatures on cylinder head surface at different loads of $0 \mathrm{~kg}, 5 \mathrm{~kg}, 10 \mathrm{~kg}$ and $15 \mathrm{~kg}$ using thermocouples with their locations from the exhaust valve centre were tabulated as shown in Table 3.

The measured values of temperature at different loads of $0 \mathrm{~kg}, 5 \mathrm{~kg}, 10 \mathrm{~kg}$ and $15 \mathrm{~kg}$ are plotted with respect to their positions from the exhaust valve centre shown in figure 8 .

The positions of various thermocouples from exhaust valve centre are plotted with figure 9.
Table 3. Measured values of Temperatures at different loads using thermocouples and their locations from exhaust vale centre

\begin{tabular}{|c|c|c|c|c|c|c|}
\hline $\begin{array}{c}\text { Applied } \\
\text { Load in kg }\end{array}$ & - & ن & m & ن & ما & ๑ \\
\hline 0 & 75 & 61 & 78 & 63 & 181 & 228 \\
\hline 5 & 78 & 64 & 81 & 64 & 182 & 232 \\
\hline 10 & 84 & 67 & 85 & 68 & 184 & 252 \\
\hline 15 & 91 & 74 & 93 & 75 & 188 & 266 \\
\hline $\begin{array}{l}\text { Distance } \\
\text { From Ex- } \\
\text { haust Valve } \\
\text { Centre in } \\
\text { mm }\end{array}$ & $\begin{array}{l}\stackrel{2}{\sigma} \\
\stackrel{\sigma}{\sigma}\end{array}$ & 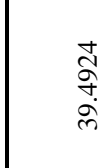 & $\begin{array}{l}\hat{\infty} \\
\hat{\delta} \\
\dot{m}\end{array}$ & $\begin{array}{l}\vec{N} \\
\tilde{n} \\
\text { fo }\end{array}$ & 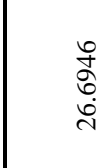 & 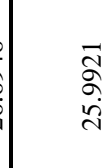 \\
\hline
\end{tabular}

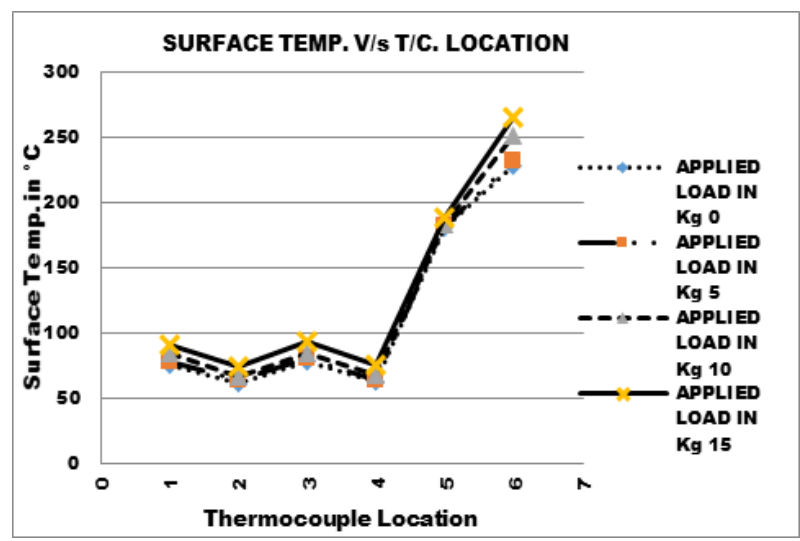

Fig. 8. Measured Temperature Values at different loads $0 \mathrm{~kg}, 5 \mathrm{~kg}$, $10 \mathrm{~kg}$ and $15 \mathrm{~kg}$

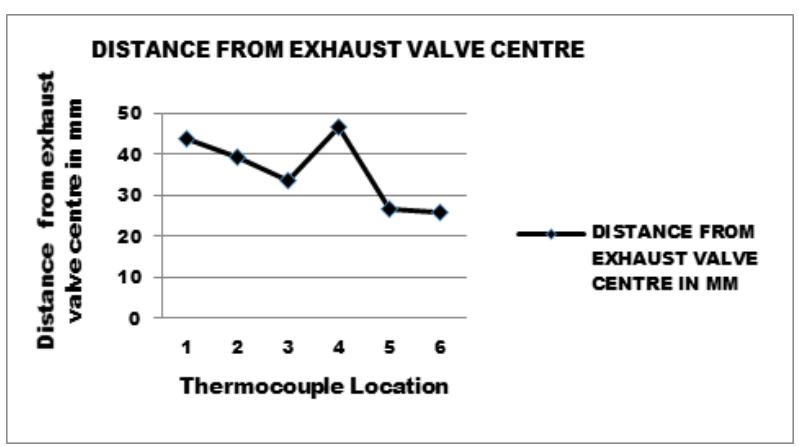

Fig. 9. Distance of thermocouple points from exhaust valve centre 
From the figure 9, it is clear that the thermocouple locations 3, 5 and 6 are nearest to the exhaust valve centre and the measured values of temperature at these locations for different loads of $0 \mathrm{~kg}, 5 \mathrm{~kg}, 10 \mathrm{~kg}$ and $15 \mathrm{~kg}$ are plotted shown in figure 10 .

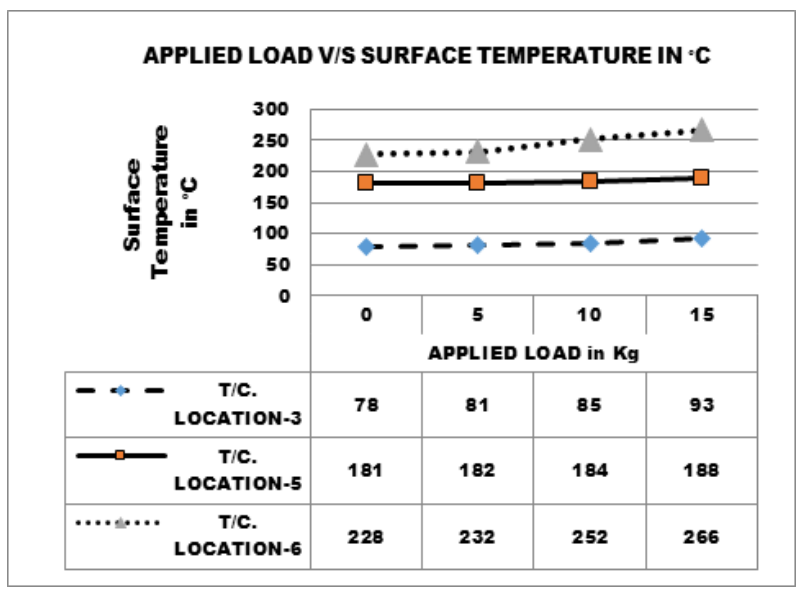

Fig. 10. Measured temperature values from thermocouple locations-3, 5 and 6 for different applied loads of $0 \mathrm{~kg}, 5 \mathrm{~kg}, 10 \mathrm{~kg}$ and $15 \mathrm{~kg}$

Engine performance parameters were calculated and recorded for various applied loads $0 \mathrm{~kg}, 5 \mathrm{~kg}, 10 \mathrm{~kg}$ and $15 \mathrm{~kg}$ as it is seen on Table 4.

Table 4. Engine performance parameters: mechanical efficiency, power, mean effective pressure, thermal efficiency, specific fuel consumption, air-fuel ratio and adiabatic flame temperature at various applied loads

\begin{tabular}{|c|c|c|c|c|c|c|}
\hline \multicolumn{2}{|c|}{$\begin{array}{c}\text { Applied Lo } \\
\text { ad } \\
\text { in } \mathrm{kg}\end{array}$} & $\begin{array}{l}\eta_{\text {mech }} \\
\text { in } \%\end{array}$ & $\begin{array}{l}\text { Brake } \\
\text { Powe } \\
\mathrm{r} \text { in } \mathrm{k} \\
\mathrm{W}\end{array}$ & $\begin{array}{c}\text { Indicated } \\
\text { Power } \\
\text { in } \mathrm{kW}\end{array}$ & $\begin{array}{l}\eta_{\mathrm{Br} . \mathrm{T}} \\
\text { hermal } \\
\text { in } \%\end{array}$ & $\begin{array}{l}\eta_{\text {Ind. } T} \\
\text { hermal } \\
\text { in } \%\end{array}$ \\
\hline \multicolumn{2}{|l|}{0} & 0 & 0 & 0.9 & 0 & 21.43 \\
\hline \multicolumn{2}{|l|}{5} & 52.40 & 0.991 & 1.891 & 22.28 & 42.52 \\
\hline \multicolumn{2}{|l|}{10} & 68.77 & 1.982 & 2.882 & 32.93 & 47.88 \\
\hline 15 & & 76.76 & 2.973 & 3.873 & 34.58 & 48.05 \\
\hline $\begin{array}{l}\text { BMEP } \\
\text { in bar }\end{array}$ & $\begin{array}{l}\text { IMEP } \\
\text { in bar }\end{array}$ & \multicolumn{2}{|c|}{$\begin{array}{c}\text { Mass flow } \\
\text { rate } \\
\text { of air } \\
\text { in } \mathrm{kg} / \mathrm{hr}\end{array}$} & $\begin{array}{c}\text { Discharge } \\
\text { of air } \\
\text { in } \mathrm{kg} / \mathrm{hr}\end{array}$ & \multicolumn{2}{|c|}{$\begin{array}{l}\text { Specific Fuel } \\
\text { Consumption } \\
\text { in } \mathrm{kg} / \mathrm{kW}-\mathrm{hr}\end{array}$} \\
\hline 0 & 1.302 & \multicolumn{2}{|c|}{25.277} & 6.016 & \multicolumn{2}{|c|}{$\infty$} \\
\hline 1.436 & 2.736 & \multicolumn{2}{|r|}{25.277} & 6.016 & \multicolumn{2}{|c|}{0.3727} \\
\hline 2.867 & 4.170 & \multicolumn{2}{|c|}{24.884} & 5.923 & \multicolumn{2}{|c|}{0.2522} \\
\hline 4.301 & 5.603 & \multicolumn{2}{|c|}{24.787} & 5.90 & & 402 \\
\hline Air/Fuel & $\begin{array}{r}\text { Mass } \\
\text { of fu } \\
\text { in }\end{array}$ & $\begin{array}{l}\text { low } \\
\text { inje } \\
\mathrm{kg} / \mathrm{h}\end{array}$ & $\begin{array}{l}\text { rate } \\
\text { ected } \\
\mathrm{r}\end{array}$ & $\begin{array}{l}\% \text { of ex- } \\
\text { cess air } \\
\text { supplied }\end{array}$ & $\begin{array}{r}\text { Adiabatic } \\
\text { Temper } \\
\left(\mathrm{T}_{\mathrm{AF}}\right) \mathrm{i}\end{array}$ & $\begin{array}{l}\text { Flame } \\
\text { ature } \\
{ }^{\circ} \mathrm{C} \\
\end{array}$ \\
\hline 72.49 & & 487 & & 88.26 & 1576 & \\
\hline 68.44 & & 3693 & & 83.30 & 1607. & \\
\hline 49.78 & & 4998 & & 60.61 & 1757. & \\
\hline 37.03 & & 6694 & & 45.08 & 1882 & \\
\hline
\end{tabular}

From the engine performance data, the variation of brake power and adiabatic flame temperature were drawn for various applied loads shown in figures 11 and 12.

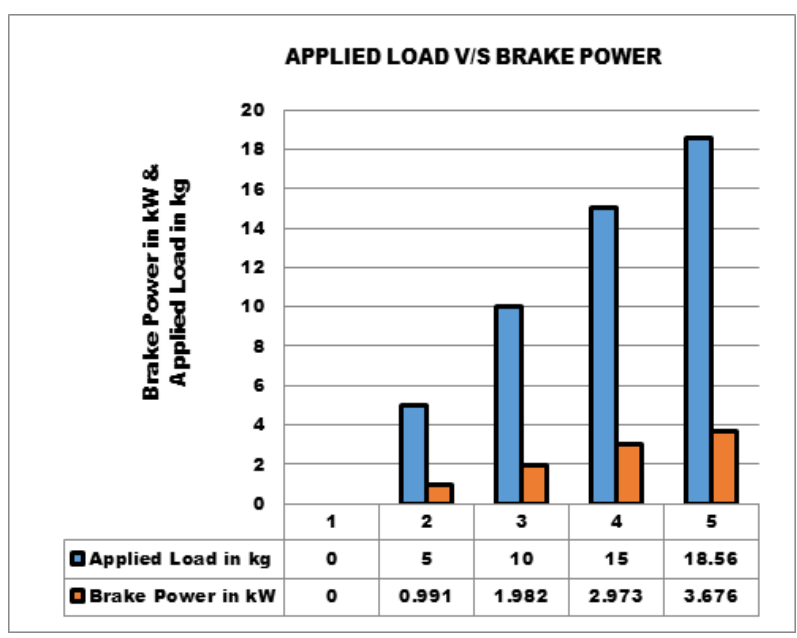

Fig. 11. Variation of brake power at various applied loads

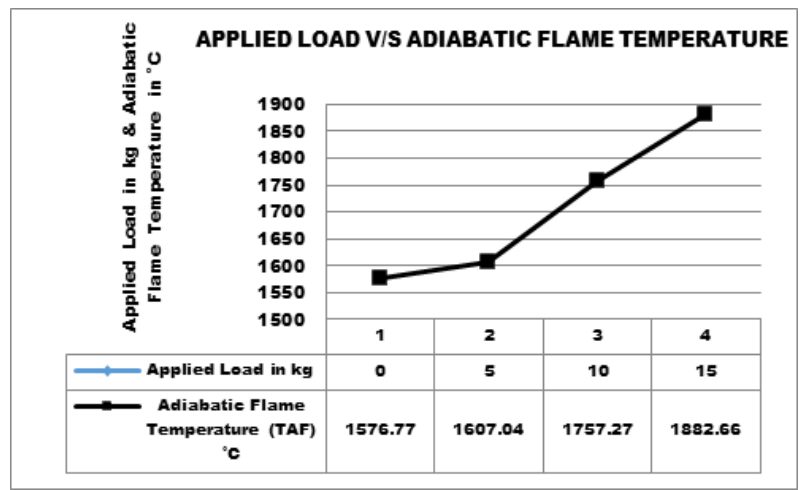

Fig. 12. Variation of adiabatic flame temperature values at various applied loads

Heat balance parameters were calculated and tabulated for various applied loads $0 \mathrm{~kg}, 5 \mathrm{~kg}, 10 \mathrm{~kg}$ and $15 \mathrm{~kg}$.

From Newton's heating (or) cooling law, the rate of heat transfer through fluid medium (or) convection heat transfer is directly proportional to the surface area of the solid and the temperature difference between the solid surface and the adjoining fluid. Therefore, the rate of convection heat transfer is given as:

$$
\mathrm{Q}_{\text {convection }}=\mathrm{h} \mathrm{A}(\Delta \mathrm{T})
$$

where, ' $h$ ' is the convection heat transfer coefficient in $\mathrm{W} / \mathrm{m}^{2} \mathrm{~K}$.

From Stefan Boltzmann law, the rate of radiation heat transfer is directly proportional to the forth power of its absolute temperature. Therefore, the rate of radiation heat transfer is given as:

$$
\mathrm{Q}_{\text {radiation }}=\sigma \varepsilon \mathrm{A}\left(\mathrm{T}_{1}^{4}-\mathrm{T}_{2}^{4}\right)
$$


where, ' $\sigma$ ' is the Stefan Boltzmann constant in $\mathrm{W} / \mathrm{m}^{2} \mathrm{~K}^{4}$. and ' $\varepsilon$ ' is the emissivity.

Table 5. Heat Balance Parameters: Heat supplied by Fuel, Heat lost through friction, Brake Power and Heat lost to - cooling water, exhaust gas, lubrication \& radiation at various applied loads

\begin{tabular}{|c|c|c|c|c|}
\hline $\begin{array}{c}\text { Applied } \\
\text { Load } \\
\text { in kg }\end{array}$ & $\begin{array}{c}\text { Heat su } \\
\text { pplied b } \\
\text { y Fuel i } \\
\mathrm{n} \mathrm{kW}\end{array}$ & $\begin{array}{c}\text { Heat lo } \\
\text { st throu } \\
\text { gh Fric } \\
\text { tion in } \\
\mathrm{kW}\end{array}$ & $\begin{array}{c}\text { Heat } \\
\text { equivalent } \\
\text { of useful } \\
\text { work (BP) } \\
\text { in kW }\end{array}$ & $\begin{array}{c}\text { Heat lost } \\
\text { to cooling } \\
\text { water } \\
\text { in kW }\end{array}$ \\
\hline 0 & 4.12 & 0.9 & 0 & 0.835 \\
\hline 5 & 4.45 & 0.9 & 0.991 & 1.003 \\
\hline 10 & 6.02 & 0.9 & 1.982 & 1.225 \\
\hline 15 & 8.06 & 0.9 & 2.973 & 0.484 \\
\hline $\begin{array}{c}\text { Heat lost throu } \\
\text { gh }\end{array}$ & Heat lost to lubri & Heat lost through ra \\
cation \\
in kW \\
in kW
\end{tabular}

The average surface temperature on the combustion chamber and average convection heat transfer coefficient values are calculated for various applied loads and the values were tabulated

Table 6. Convection heat transfer parameters: Average surface temperature and average convection heat transfer coefficient values at various applied loads

\begin{tabular}{|c|c|c|c|c|}
\hline $\begin{array}{c}\text { Applie } \\
\text { d Load } \\
\text { in kg }\end{array}$ & $\begin{array}{c}\text { Average } \\
\text { surface t } \\
\text { emperatu } \\
\text { re in K }\end{array}$ & $\begin{array}{c}\text { Exhaust ga } \\
\text { s temperat } \\
\text { ure in the } \\
\text { manifold } \\
\text { in K }\end{array}$ & $\begin{array}{c}\text { Mass o } \\
\text { f exhau } \\
\text { st gas } \\
\text { flow } \\
\text { in kg/ } \\
\text { hr }\end{array}$ & $\begin{array}{c}\text { Average con } \\
\text { vection heat } \\
\text { transfer coe } \\
\text { fficient in k } \\
\mathrm{W} / \mathrm{m}^{2} \mathrm{~K}\end{array}$ \\
\hline 0 & 474.12 & 553.66 & 25.63 & 0.1813 \\
\hline 5 & 492.14 & 438.47 & 25.65 & 0.2152 \\
\hline 10 & 525.34 & 462.54 & 25.38 & 0.2379 \\
\hline 15 & 578.16 & 514.99 & 25.46 & 0.2964 \\
\hline
\end{tabular}

As adiabatic flame temperature increases with increase in applied load on the engine, the average surface temperature on the combustion chamber also increases by combined convection and radiation heat transfer modes. Figure 13 shows the variation of average surface temperature on combustion chamber for various applied loads.

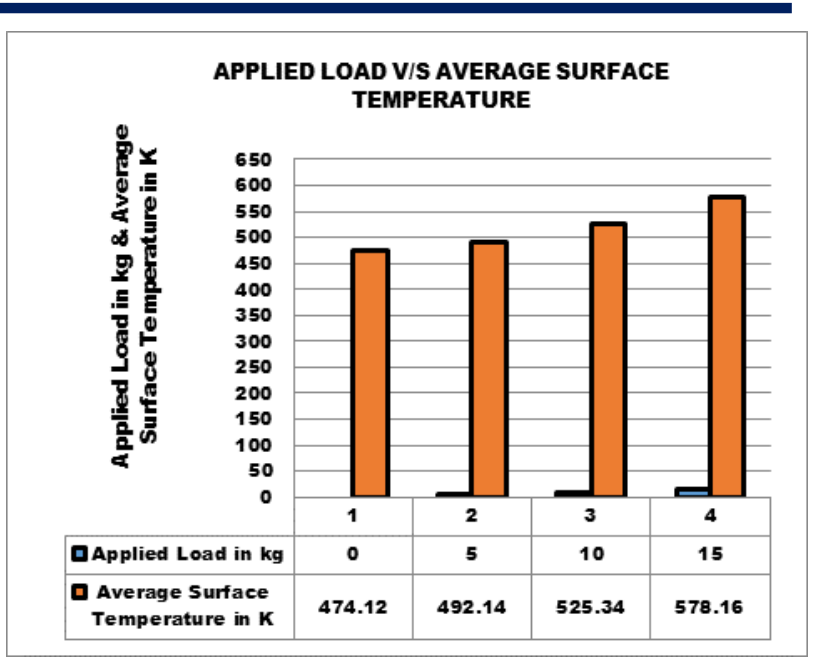

Fig. 13. Variation of average surface temperature on combustion chamber for various applied loads

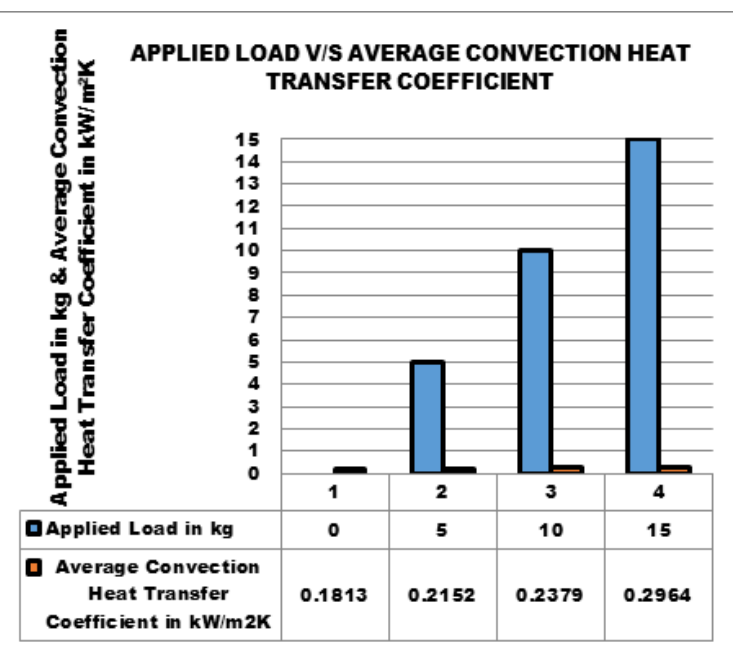

Fig. 14. Variation of average convection heat transfer coefficient from exhaust gas to combustion chamber surface at various applied loads

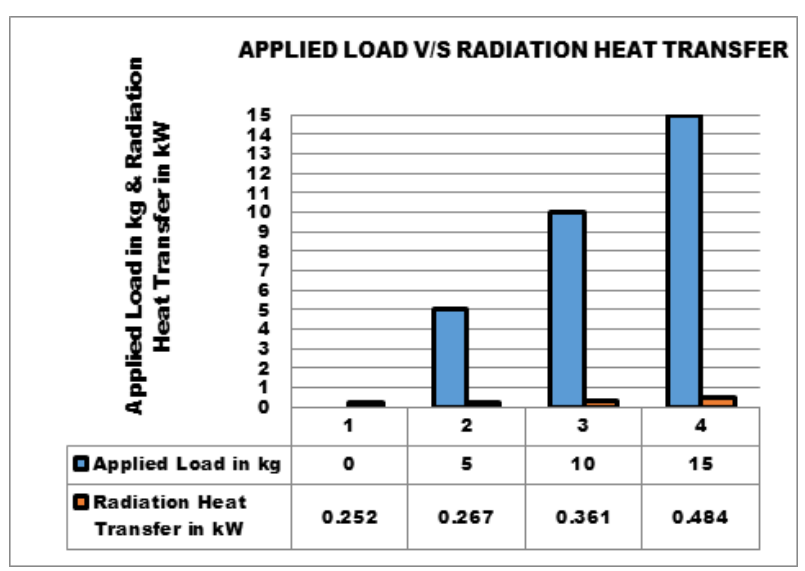

Fig. 15. Variation of radiation heat transfer from exhaust gas to combustion chamber surface for various applied loads 
The amount of radiation heat transfer is directly proportional to the fourth power of its absolute temperature. In this case, the rate of radiation heat transfer increases with increase in in-cylinder (or) exhaust gas temperature. Figure - 15 shows the variation of radiation heat transfer from exhaust gas to combustion chamber surface for various applied loads. Here, the rate of radiation heat transfer increases by increasing the in-cylinder (or) exhaust gas temperature due to increase in applied load.

From the obtained values of radiation heat transfer from exhaust gas to combustion chamber surface for various applied loads, the emissivity values due to radiation heat transfer are calculated.

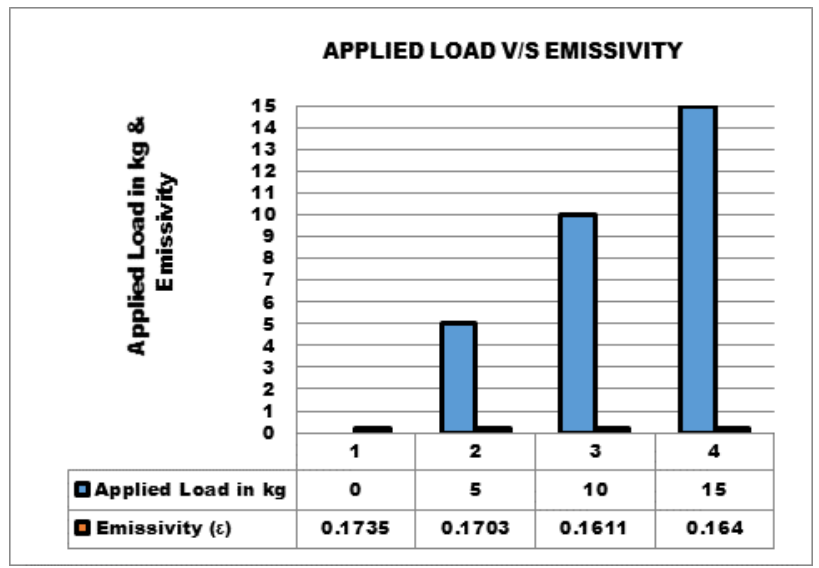

Fig. 16. Variation of emissivity values at various applied loads

Figure 16 shows that the emissivity value is higher at no load and then decreases when applied load increases. Finally the emissivity value decreases slightly due to approximately the same surface temperature of combustion chamber with the exhaust gas temperature.

\section{Results and Discussions}

From the obtained values of adiabatic flame temperature, temperature on cylinder head surface exposed to combustion chamber, convection and radiation heat transfer values, convection heat transfer coefficient and emissivity values, and heat balance data of a diesel engine, it is required to modify the surface profile of combustion chamber by imparting the hot spot regions at proper locations which support complete combustion in order to improve engine performance and also to control/reduce the harmful emissions from diesel fuel combustion. Also the modified profile of combustion chamber impart swirl and squish effects by keeping in mind the hot spot regions, results in better performance and reduction in harmful emissions.

\section{References}

[1] Heywood JB. Internal combustion engine fundamentals. New York: McGraw-Hill, Inc; 1988.

[2] Venkateswarlu, C., Subramanian, K.A., (2016). CFD analysis on effect of localized in-cylinder temperature on nitric oxide (NO) emission in a compression ignition engine under hydrogen-diesel dual-fuel mode. Energy 116, 470-488.

[3] Blevins, L.G., Fletcher, R.A., Benner, B.A., Steel, E.B., Mulholland, G.W. (2002). The existence of young soot in the exhaust of inverse diffusion flames. Proc. Combust. Inst., 29, 25-33.

[4] Lee, E.J., Oh, K.C., Shin, H.D. (2005). Soot formation in inverse diffusion flames of diluted ethene. Fuel, 84, 543550.

[5] Oh, K.C., Lee, U.D., Shin, H.D., Lee, E.J. (2005). The evolution of incipient soot particles in an inverse diffusion flame of ethene. Combust. Flame., 140, 249-54.

[6] Jung, Y., Oh, K.C., Bae, C., Shin, H.D. (2012). The effect of oxygen enrichment on incipient soot particles in inverse diffusion flames. Fuel, 102, 199-207.

[7] Dec, J.E.A., (1997). Conceptual model of diesel combustion. SAE technical paper 970873.

[8] Kosaka, H., Aizawa, T., Kamimoto, T. (2005). Twodimensional imaging of ignition and soot formation processes in a diesel flame. Int J Engine Res, 6, 21-42.

[9] Nieman, D.E., Dempsey, A.B., Reitz R.D. (2012). Heavyduty RCCI operation using natural gas and diesel. SAE International Journal of Engines, 5, 270-85.

[10]Splitter, D.A. (2012). High efficiency RCCI combustion. United States - Wisconsin: The University of Wisconsin Madison; 2012. p. 320.

[11]Splitter, D., Hanson, R., Kokjohn, S., Reitz, R. (2011). Reactivity controlled compression ignition (RCCI) heavyduty engine operation at mid-and high-loads with conventional and alternative fuels. SAE technical Paper (2011-010363).

[12]Zheng, M., Mulenga, M.C., Reader, G.T., Wang, M., Ting, D.S.K., Tjong, J. (2008). Biodiesel engine performance and emissions in low temperature combustion. Fuel, 87, 714722.

[13]Caliskan, H., Ertunc, M., Arif Hepbasli, T.A. (2009). Performance assessment of an internal combustion engine at varying dead (reference) state temperatures, Applied Thermal Engineering 29 (2009) 3431-34.

[14]Hoseini, S.S., Najafi, G., Ghobadian, B., Mamat, R., Yusaf, T. (2018). Experimental and Numerical Analysis of Flow and Heat Transfer Characteristics of EGR Cooler in Diesel Engine, Applied Thermal Engineering, 140, 745-758.

[15]Shahanwaz, K., Rajsekhar, P., Probir, K.B., (2018). Combined effects of piston bowl geometry and spray pattern on mixing, combustion and emissions of a diesel engine: A numerical approach, Fuel, 225, 203-217.

[16]Matteo, S., Andrea, B., Fabrizio, D., (2018). Assessment of the wall heat transfer in 3D-CFD in-cylinder simulations of 
high performance diesel engines, Energy Procedia, 126, 963-970.

[17]Slavey, T., Leonardo, P., Öivind, A., Zhenkan, W., Mattias, R., José, V.P., José, M.G., Antonio, G., (2018). Influence of spatial and temporal distribution of Turbulent Kinetic Energy on heat transfer coefficient in a light duty CI engine operating with Partially Premixed Combustion, Applied Thermal Engineering , 129, 31-40.

[18]Torregrosa, A.J., Broatcha, A., Olmeda, P., SalvadorIborraa, Warey, J.A. (2017). Experimental study of the influence of exhaust gas recirculation on heat transfer in the fire deck of a direct injection diesel engine, Energy Conversion and Management, 153, 304-312.

[19]Yuan, C., Feng, H., He, Y., (2017). An experimental research on the combustion and heat release, characteristics of a free-piston diesel engine generator, Fuel, 188, 390400 .

[20]Zheng, Z., Liu, F., Yifeng, A., Haobo, G., Wei, D., Yongli, G., Juejue, L., (2018). Effect of wall surface temperature on ignition and combustion characteristics of diesel fuel spray impingement, Applied Thermal Engineering, 137, 47-53.

[21]Shivakumar, N., (2017). Temperature Distribution Measurement on the Combustion Chamber Surface of Diesel Engine - Experimental Method, International Journal of Automotive Science and Technology, 1(3), 8-11. 